\title{
Restructuring, National Security and Nigeria's Relationship with the External World
}

\author{
Agidi Ejime Pally \\ http://dx.doi./org/10.4314/ujah.v21i4.2
}

\begin{abstract}
Nigeria as a nation has been experiencing security challenges at alarming level in the last few years. This has taken various forms such as kidnapping from ransom, herders and farmers clashes, organized crimes, and cybercrimes, implosive movement of small and light arms. Trans border crimes, human trafficking, and slavery among others. This has affected Nigeria's external relations with the outside world negatively in various ways, such as constriction of bilateral trade volume, cold diplomatic relations, low tourism attraction, low educational exchange, reduction of military trainings abroad, refusal of arms purchase, low foreign investments among others. The diversity nature of the Nigerian state stands a gap in finding solutions to the myriads of problems as Nigeria's image abroad has been dented badly. Restructuring the Nigerian state in various spheres has been the agitation of many Nigerians in the recent time. This paper therefore examines restructuring the Nigerian state, National security and its implications on her relationship with the external world. It is a qualitative paper that focused on secondary sources of information, and adopted structural functional theory as its framework of analysis. The paper argued that restructuring the political structures in Nigeria will advance quality security in Nigeria. It is the opinion of the paper that improves security in the country will enhance robust Nigerian's relationship with the external world. The paper recommended among others, the restructuring of political economic and social structures through the instrument and legitimacy of national conference. This has to be backed by legislations from the national and state assembly.
\end{abstract}


Keywords: Restructuring, External Relationships, National Security, Political Structure, National Conference

\section{Introduction}

Nigeria is a multi ethnic nation with over 250 diverse ethnic groups brought together at independence as one nation. The 1960 Independence constitution made Nigeria a Federal State with three Federating units and later by 1963, four federating units with adherence to true Federalism. The subsequent years of military rule changed the practical true federalism to principle federalism where the centre has over bearing power over the federating units. Inequality and lopsidedness in the economic, political and social sectors in Nigeria became very apparent. This occasioned series of insecurity issues ranging from Boko Haram. Insurgency, herdsmen/farmers unhealthy relationship, kidnapping for ransom, human trafficking, internal slavery, cybercrimes, implosive movement of small and light arms, Trans border armed, organized crimes, boundary clashes, religions to electoral violence. This has affected Nigeria's external relations with the outside world in various ways such as low tourism, low educational exchange, and refusal to sell arms to Nigeria to fight insurgency, bad image abroad, reduction of trade volume, low foreign investment, refusal to grant visa to Nigerians wishing to travel outside the Nigeria, cold diplomatic relations among others. There is obvious lack of political will and capacity by the government to abate the ugly situation. This had occasioned the demand for restructuring Nigeria so as to achieve good atmosphere for peace and security which will pave way for a robust external relations with the outside world. This paper therefore examines restructuring, national security and Nigeria external relations with the outside world. 


\section{Conceptual clarifications \\ Restructuring}

The concept of restructuring is not new in Nigerian politics but it gained currency and occupied centre stage in Nigeria political discourse since the fourth democratic dispensation. Restructuring in Nigeria attracted voices from both partisan and non partisan citizens which raised its level as a serious matter. It has become a form of potent agitation from different protagonists and had equally attracted challenges from many antagonists. Different scholars have defined it from different perspectives at different times. In most cases, it has been interchangeably used and interpreted with federalism. However, further clarification to show that the two concepts do not connote the same thing is important. To restructure refers to modify, change, reorganizes or rearrange the existing status quo. This could be rescheduling of debt repayments, rearranging the organogram of a company, changing the channel of movement in an organization or rearranging the political arrangement that has been in existence. Restructuring could refer to the act of reorganizing the operational and the structure of a company or organization for the purpose of making it more profitable or better organized for its present needs. In the current political discourse in Nigeria, restructuring refers mainly to political restructuring. In other words restructuring could take many forms such as political restructuring, economic restructuring, cultural restructuring, educational restructuring, social restructuring and many more.

Obiora (2018) defined restructuring as a change of the existing system or status quo in order to make it more functional. Abbas and Wakili (2018) opined that restructuring in the context of Nigeria is regarded as a persistent campaign and agitation for the political reorganization of Nigeria's government as well as other aspects desired for a constitutional amendment. Adeogun (2019) sees restructuring as the restoration of federalism with independent self- 
sustaining federal units able to develop infrastructure, critical amenities undertake other projects, education and health without a central body interfering. Bello (2017) stated that restructuring is the process of increasing or decreasing the number of component parts that makes up a system and re-defining the inter-relationship between them to ensure efficiency of the entire system. To Agidibi (2019) restructuring is all about the re-constitution of everything that makes up the Nigeria politics.

From the above definitions, restructuring connotes that states in Nigeria should be permitted by law to own and manage their resources and authorized to initiate or execute development in their states without interference from the centre. A call for restructuring Nigeria now means a call for the review of 1999 constitution of the Federal Republic of Nigeria. It means the devolution of powers of the Federal Government such that more responsibilities be given to the states while the while the Federal government is vested with the responsibility to oversee foreign policy and defence. It is a strategy aimed at bringing government as close as possible to the people at the grassroots.

In Nigeria political terrain, restructuring refers to the idea of re-arranging, repositioning or re-constituting the Nigeria state in various sectors. In other words, restructuring in Nigeria politics will mean that the federating units have control of the resources on their territory and pay a part as royalty to the central government.

The federating states or units will be in full charge of the mineral resources and other forms of generating fund. Idemba (2018) asserted that restructuring in Nigeria involves a revolutionary or evolutionary manner of allowing different states, ethnic nationalities and regions to control their resources and execute their developmental projects without the interference of the federal government.

Political restructuring means an arrangement whereby a decision on public policy issue is shifted from one level or tier of 
government to another. Political restructuring does not mean the mere splitting or balkanization of the existing states in Nigeria but giving more power, authority and influence to the states thereby reducing the over bearing power, authority and influence of the centre over the states. It therefore connotes that the federating states or units will have the power to adjudicate and control the resources within their states. It further means that the states should have power without having to take permission from the centre to decide on what to do for their citizens. Political restructuring therefore entails an arrangement that will guarantee that policy decisions moves from one level of the government to another. It means the devolution of power of the central government and accord the federating units substantial power to operate on core areas. However, the umbilical cord that binds the states and federal is not to be totally cut as the states should allocate a specify part of what they generates to the federal government as royalties.

Restructuring in Nigeria is another way of calling for true federalism. True federalism is a system that operates based on shared responsibility of individual units while having a central core that binds everyone together. The idea is for every region or unit to run their affairs, create wealth by harnessing and managing their resources while making some commitments to the federal and central government. Economically the units must be distinct and independent while other areas can be negotiated such as the military. The scope of practical true federalism extends beyond fiscal policies and permeates into other affairs of the state. True federalism can only be achieved by complete adherence to constitutional stipulations. The dominant element of true federalism is constitutionalism.

\section{National Security}

The concept of national security has been an important part of political and military studies that cannot be ignored in national and 
international politics. It however became more popular in the USA after the Second World War and its focus was more on military affairs but over time as the world politics changes, its scope extended beyond the military affairs to include other spheres such as economic security, energy security, food security, environmental security, cyber security, social security and other national security indices.

Overtime several scholars have defined national security from different perspectives at different time. Yet, no one definition has been widely accepted as a single definition for it as a concept, hence, its meaning remains ambiguous. Lasswell (1950) noted that the concept of national security remains ambiguous, having evolved from simple definitions which emphasized freedom from military threat and from political coercion. Paleri (2008) posited that National Security is the measurable state of the capability of a nation to overcome the multi-dimensional threats to the apparent well being of its people and its survival as a nation-state at any given time by balancing all instruments of state policy through governance and is extendable to global security by valuables external to it. Maier (1950) noted that National Security is best described as a capacity to control those domestic and foreign conditions that the public opinion of a given community believes necessary to enjoy its own self determination or autonomy, prosperity and well being. The above definitions exposed the facts that national security is not restricted to international military politics. Harold (1983) described national security as the ability to preserve the nation's physical integrity and territory to maintain its economic relations with the rest of the world on reasonable terms, to preserve its nature, institutions and governance from disruption from outside and controls its border. The various definitions above exposed the importance of national security which is the major function of any government in power in any nation. In other words, its means that national security is said to exist in a nation when there is absence of security threat to its core values, 
and when a nation does not have to sacrifice it's legitimate or core interests so as to avoid war. Therefore National Security could mean a situation or condition where a nation is able to guarantee the protection of its citizens, various institutions, investments economy, provision of foods and creation of absolute security devoid of fear and anxiety within the nation. The most important function of any government is the protection of lives of her citizens and their properties from various security threats. It is the duty of any government in power to ensure national security by providing atmospheres for security to thrive within the nation. This is done by collaborating with various sectors and nationals and international stakeholders to minimize insecurity occasioned by different challenges around the globe such as arms proliferation, climate change, economic disorder and the north/South dichotomy. Aliyu (2012) noted there is an attempt to broaden the issue of security to accommodate other relevant elements such as economic development, equality, political accountability and good governance.

National Security being an important role of any government which is to protect the lives of her citizens and their properties from security threats could be achieved and maintained by:

1. Having and maintaining efficient and effective armed forces

2. Maintaining cordial relationship with allies and friends

3. Building strong economic power that will bring cooperation's among the citizen

4. Employing the use of intelligence services to avoid threats from external and internal.

5. Checkmating sabotage of government security initiatives

6. Countering of internal security threats that could snowball into international security threats.

7. Detecting and controlling of terrorists activities

8. Ensuring equitable distribution of resources available

9. Ensuring good governance. 


\section{Reasons or the Needs for Restructuring in Nigeria}

The demand for restructuring in Nigeria has continued to gain ground with laud voices in almost every part of Nigeria. The apologists of political restructuring in Nigeria believe that it will attract various benefits to the entire nations.

1. Security: Nigeria is presently saddled with security problems in every corner of the country. The security problems have overwhelmed the government to the extent that they are calling for external aid. The Boko Haram in the North East, the Herdsmen and farmers clashes, the kidnapping for ransom are on the increase on daily basis across the country. One of the major functions of government which is the protection of lives and properties of the citizens within the territory is visibly lacking in Nigeria. However if Nigeria is restructure the security load on the federal government will be drastically reduced as the federating states will be responsible for police, and other paramilitary outfit. This will enhance the security in the entire nations.

2. Education: Presently in Nigeria, the educational system entrust the policy on education to the federal government. This has over the years affected the growth of the educational system. Restructuring will improve the educationally system because the states will be in charge of their education. The quality of education will be raised as the states will initiate educational policies, execute the policies and regulate the entire education system.

3. Electricity: Power generation and distribution in Nigeria has been at a minimal production, because the power distribution is controlled by the federal government. No state or private individual can build power generating outfit without getting permission to link it to the national grid. This has discouraged many states and private investors from venturing into the power 
sector. This has resulted to low efficiency as the work load is too much and heavy for the federal government alone to manage. Restructuring will allow states to build generate and manage their own power. This will bring efficiency and effectiveness to its optimum and raise the overall power development.

4. Healthy competition: Restructuring will enhance healthy competition among the federating states in many sectors. This will lead to better innovations, inventions and initiations. Embezzlement will be highly reduced as each state will create her own internal mechanism of controlling various sectors.

5. Presently in Nigeria, many regions, and groups continues to demand for separation from the federal government. This is a way of expressing their dissatisfaction of the way the federal government relates with the state government. Restructuring will halt the agitation for separation from the states, and the cries for marginalization will be reduced to the barest minimum. The desire to break away from the Nigeria federalism by the federating states in Nigerian politics is as a result of dissatisfaction experienced by the federating units.

6. Restructuring in Nigeria will encourage meritocracy and reject mediocrity. Persons with genuine interest, impeccable character, sound track records of acceptable reputation will have the opportunity to contribute their quota to the development of the country.

7. Restructuring will enhance leadership quality, build quality political culture, encourage good political socialization and enhance political participation and interest.

8. Restructuring in Nigeria will discourage the current practice of federating states depending on monthly federal allocations. States will be encouraged to initiate avenues of generating fund to develop their regions. 
9. Corruption, looting of public treasury, awards of fathom contracts will be highly eliminated.

10. Restructuring will enhance good governance where the dividends of democracy will be equitably distributed to the people

11. Restructuring will form the bedrock to sustain the political development in Nigeria. It will propel growth, prosperity and wealth

\section{Challenges to Restructuring in Nigeria}

The issue of restructuring has become a form of potent agitation from different protagonists and has attracted challenges from many antagonists who do not see any merit in it. In other words, the call for restructuring is faced with many challenges, which include:

1. The 1999 constitution of the Federal Republic of Nigeria as amended has very strict, rigid and cumbersome processes of making any change. The complexity in the processes of amending the constitution stands as a huge hindrance on restructuring in Nigeria. Restructuring process itself connotes enormous review of amendment of the constitution which must pass through the rigorous path of rigidity.

2. Another challenge to the agitation of restructuring in Nigeria is lack of proper conceptualization of the subject matter to the understanding of both the protagonists and the antagonists of the agitation. Many elites especially those who are against restructuring misunderstand it and therefore misinterpret its meaning. Also most crusaders of restructuring lack the knowledge of the meaning and therefore find it difficult to explain it to those who are against it.

3. There is fear of breaking Nigeria into several republics. Many Nigeria nurses the fear that restructuring Nigeria could led to balkanization of the Nigerian state into many autonomous units. 
4. Most advocates of restructuring hinges their reasons of clamouring for restructuring on imbalance in federal structure, government and distribution of resources. The above argument has always been a point of reference to most antagonist of the agitation for restructuring because they believe that the constitution is very explicit on various subject

5. The call for restructuring Nigeria has also attracted economic critics who believe that those who are advocating for it, has hidden personal agenda which is capable of dismembering entire nation into smaller units.

6. Some citizens believe that the call for restructuring is indirectly promoting sectionalism and secession among the various regions who feels marginalized. These agitators had been accused of calling for separation rather than calling for unity in diversity. It therefore means that the very foundation of Nigeria nation has become threatened by the agitation for restructuring.

\section{Security Challenges in Nigeria}

Nigeria as a nation has been fighting various forms of insecurity since independence. This has heightened in the recent time especially since the last few years. Some notable security challenges that had troubled Nigerian state in the recent time are:

1. Boko Haram: This group is made up of militant Islamist group that has destabilized activities in the North Eastern Part of Nigeria since 2009. Their activities had resulted into many people residing in IDPs camps and over 2.5 million people fleeing their ancestral home to become refugees in another territory. The Boko Haram group had engaged in laying of ambush to attack both the civilian and the military, kidnapping, killing and destruction of properties.

2. The Islamic Movement of Nigeria led by Ibrahim, Zakzaky has been opposing the federal government of Nigeria. The activities 
of this group have resulted into clashes with the state security where many persons and properties had been destroyed. In 2015, the leader of the group was arrested and that has heightened the security challenges to very high levels.

3. Electoral Violence: Since 1999, the electioneering process in Nigeria has been characterized by violence in one form or the other. For example, the October 2019 general election was characterized by several electoral violence's. According to the Nigeria civil society situation Room (NCSSR) an estimated 626 persons were killed across Nigeria in the six months between the start of the election campaign in October 2018 and October 2019. According to the report, the North West region recorded the highest number of deaths with 172 killed during the fatalities. South South recorded 146 killed, North central had 120, south West 63 while South East 14 respectively.

4. Communal Conflicts: The conflicts between communities that has common boundary in Nigeria has been on the increase. It cuts across communities in the same local government, different local governments and different states. In most cases the presence of mineral resource form the basis of the clashes. This has degenerated to serious acrimonies and threats on security of the nation.

5. Herdsmen and Farmers clashes: The clash between the nomadic herdsmen and sedentary farmers which was more pronounced in the middle belt of Nigeria has currently spread to other parts of Nigeria. The nomadic herders are mainly Muslims Fulanis while the farmers are mainly Christians from Tiv, Jukun, Hausa and other tribes. Most people had interpreted their clashes from either religion or ethnic perspective. The disagreement has always been that the herders take their animals across the farms of the sedentary farmers and their crops are either destroyed or consumed by the animals. This has resulted to huge lost of live, 
properties and other materials. The security of the nation is highly threatened by this trend of herders and farmers clashes.

6. Kidnapping: Kidnapping for ransom has been very prevalent in every part of Nigeria in the recent time. This is one of the major security threats that have not been abated in Nigeria. There are several cases of kidnapping recorded in Nigeria. In most cases, this kidnapping is linked to the herdsmen.

7. Herdsmen occupation of Southern forests: This is yet another great threat to Nigeria security. It has been observed that in the recent time, the herdsmen from the northern part of Nigeria brought their cattle to occupy the forests in the southern part of Nigeria. They chases the owners of the forests away, build their houses and establish cattle colony. They rape the women and kidnap the men that originally own the forests. This brings clashes between the owners of the forests and the herdsmen who have come to occupy their lands.

Other security challenges in Nigeria include cybercrimes, cultism, human trafficking, implosive movement of small and light arms, trans border crimes and organized crimes.

\section{Restructuring, National Security and Nigeria relations with the external world}

Since independence, Nigeria's relationship with the external world has been dominantly characterized by her focus on Africa as the centre piece of her foreign policy. She had maintained a hegemonic position in African region by observing some basic principles such as African unity and independence, peaceful settlement of disputes, nonalignment and non interference in internal affairs of other nations and regional economic cooperation's and development. Nigeria participates actively in African Union, ECOWAS, the Non Alignment 
Movement, the Common Wealth of Nations and United Nations Activities.

Nigeria maintains relationship with the external world in the following ways among others. Establishment and promoting of bilateral relationships with other nations, peaceful settlements of disputes, participating in peace keeping operations establishing of foreign mission abroad and granting other nations to establish theirs in Nigeria, promoting cultural, sporting, educational and exchange programme and activities of receiving and caring for refugees from other countries, as well as hosting regional and sub-regional conferences and summits. The above and many other forms of relating with the external world had earned Nigeria the name, big brother of Africa, and the giant of Africa. The relationship had equally helped Nigeria to increase her trade volume, increase development and improved the standard of living of her citizens over the years.

The internal policies of a nation determine to a very large extend the relationship she will keep with other nations. It therefore means that when there are good policies in a nation, it will attract robust relationship with other nations. In other words, it is only when a country possesses good governance internally that she can have national security which is a sine qua non to maintain a robust external relationship with other nations. There has been a steady rise of insecurity in Nigeria in the recent time. Nigeria government has not been able to reduce the growth of insecurity in the nation as a result of bad leadership. According to Adeyamo (2011) the nonchalant attitude of the Nigeria government in the discharge of her primary responsibility of ensuring security over the years has made insecurity to be on the rise. Also Bankong-obi (2021) opined that Nigeria intractable security challenges to the government, has been as a result of the apparently and inefficiency of the Nigeria security agencies. It 
is obvious that the security challenges in Nigeria could not be abated because of government insensitivity to security issues.

There has been a general dissatisfaction of the state of things in Nigeria in the recent time as a result of insecurity. This has generated the agitation for restructuring. Though restructuring could not be seen as new in Nigeria political history. Over the years, Nigeria has been restructured in areas of state and local government administrative styles. But there has been a loud shout for new forms of restructuring because of the inadequacies that were not accommodated in the earlier restructuring. The protagonists of restructuring believes that when Nigeria is restructure, the aged long insurgency, banditry, Herders/farmers, clashes will be abated. This will bring good governance, peace and sustainable development and enhance robust relationship with the external world. As a result of the insecurity in Nigeria, her relationship with the external world had been affected leading to reduction of bilateral trade volume, could low tourism attraction, low educational exchange, reduction of military training abroad, refusal to sell arms to Nigeria to fight insurgents, low foreign investment, and bad image among others.

\section{Conclusion}

The study critically and carefully examines the meaning of restructuring, its benefits and challenges. The study further examines the meaning of national security, its benefit and its challenges. It also looked at Nigerians relationship with the external world and the benefits and conditions of having relationship with, the external world. The paper indentified the nexus between restructuring, national security and Nigeria relationship with the external world. The paper discovered that Nigeria as a state is heavily threatened by various forms of insecurity. The paper is of the opinion that the corporate existence of Nigeria cannot be guaranteed if the security situation is not improved. The paper also noted that the security management and 
control has overwhelmed Nigeria state as a result of her insensitivity to security issues. The paper further noted that the spate of insecurity around every part of Nigeria prompted the agitation for restructuring. The paper noted that the spate of insecurity in Nigeria has been affecting her relationship with the external world in one form or the other. The paper concluded that restructuring Nigeria will help to abate the spate of insecurity in Nigeria which will further enhance her robust relationship with the external world.

\section{Recommendations}

a. Restructuring should be embraced by Nigerians as it has been seen as a way to abate insecurity and achieve national security.

b. The political elites, and professionals who understands the concept of restructuring should educate the masses on it so as to reduce the antagonism on restructuring

c. Restructuring in Nigeria should be all inclusive to touch political economic and security aspects among other areas.

d. Restructuring Nigeria is another way of constitutional amendment; therefore all stakeholders should be involved in the business of restructuring so that an acceptable result will come out of the exercise.

e. Security is not an individual business, so all citizens must be involved in the pursuit of security in Nigeria. It is important also that every stakeholder is involved in restructuring so as to achieve the status of securing every life and property in Nigeria.

f. Government should engage in collaborative efforts with her neighbouring countries such as Niger, Chad, and Cameroon to fight the insurgents so as to abate the spate of insecurity in the country.

g. Nigeria should call on international bodies and her friends in other regions to help her fight the insurgent and abate the 
insecurity, because it is obvious that the deteriorating security situation had overwhelmed the nation.

h. Nigerian government should motivate the security personnels adequately so that they will be proud of their profession and fight the insurgent.

i. Government should ensure that every part of the country is under the protection of the federal government and give equal treatment in management and control of insecurity.

j. Nigerian government should purchase up to date arms for the security operatives to perform the task ahead of them. It has always been difficult for Nigerian security fighting with substandard weapons as against the insurgent with modern weapons

k. Strigent laws should be put in place to punish offenders of the law such as kidnapping banditry, organized crime, human trafficking and other related crimes.

1. Nigeria government should adopt state policing, a system whereby every state in the country will be authorized to form their police.

m. Local vigilante should be recognized within various communities to beef up the security in every community.

Agidi Ejime Pally, PhD

Department of Political Science

College of Education, Agbor

agidipally@gmail.com 


\section{References}

Abbas, A.I \& Wakili, S.B (2018) Agitation for Restructuring and Resource Control in Nigeria Federalism: Issues, perspectives and the way forward. Convened University, Journal of Politics and International Affairs. (6) 1, 1-18

Adejumo (2011). The problems and challenges of insecurity in Nigeria (online) available https://news diary online:com./tok security htmp (April 23, 2014).

Adeogun, A.A. (2017) Nigeria Unity Depends on Restructuring: An Intervew by leadership Newspaper, June, 2017

Agidigbi, S.O. (2019) Restructuring Nigeria: Panacea to sustainable Development. Benin City. Liberty Publications. Pp 28-29

Aliju, M.K. (2012) Nigeria's security challenges and the crisis of Development: Towards a new framework for analysis. International Journal of Developing societies (1) 3 pp 107116

Bankong-obi, N. (2012) Remorseless Killers (Online) Available http://pm newsniggeria.com.2012/10/remorseless-killers/April 21, 2014).

Bello, S.A. (2017) Restructuring Nigeria: A critical analysis. This day Newspaper, June $11 \quad 2017 . \quad$ Retrieved https/www.thisdaylive.com/ index.php/2017/06/11/restructuring Nigeria-a-criticalanalysis/on 22/9/2018.

Harold, B. (1983) Thinking about National Security: Defence and foreign policy in a dangerous world. As quoted in Watson, Cynthia Ann (2008) U.S. National Security in reference handbook contemporary world issues

Idemba, O. (2019) The challenges of political Restructuring in Nigeria and the future of federalism. Awka, Anolion publishing house. P.35 
Maier, C. (1990) Peace and Security for the 1990s unpublished paper for the Mac Arthur fellowship program, social science research council 12 June 1990

Obiora, O. (2018) The value of Diversity: Restructuring to save Nigeria. An Inaugural Lecturer presented at the University of Nigeria, Nsukka, Nigeria.

Paleri, P. (2008) National Security Imperatives and challenges. New Delhi. Tota macraualti 